\title{
Fourth Issue of Journal of Materials Research Goes to Press
}

The fourth issue of Volume 1 of Journal of Materials Research will be published shortly, reports Editor-in-Chief Charles B. Duke. This issue, to be published less than nine months after the inception of the journal, includes the following:

\section{Articles}

A Method for Interpreting the Data from Depth-Sensing Indentation Instruments by M.F. Doerner and W.D. Nix.

Alpha-Recoil Damage in Zirconolite $\left(\mathrm{CaZrTi}_{2} \mathrm{O}_{7}\right.$ ) by G.R. Lumpkin, R.C.Ewing, B.C. Chakoumakos, R.B. Greegor, F.W. Lytle, E.M. Foltyn, F.W. Clinard, Jr., L.A. Boatner and M.M. Abraham.

Electron-Beam-Stimulated Processes at CdS Surfaces Observed by Real-Time Atomic-Resolution Electron Microscopy by D.J. Smith and D.J. Ehrlich.

Fabrication Process, Experimental Results and Application for an Elemental Level Vertically Integrated Circuit (ELVIC) by $T$. Enomoto.

Factors Influencing the Stability of the Tetragonal Form of Zirconia by R. Srinivasan, R.J. De Angelis and B.H. Davis.

Growth and Photoluminescence Characterization of ZnSe Layers Grown on (100) Ge by Molecular Beam Epitaxy by R.M. Park and H.A. Mar.

On the Kinetics of Thermal Donor Formation in Silicon by J.T. Borenstein, D. Peak and J.W. Corbett

Preparation and Crystal Properties of the Thin InSb Films for Highly Sensitive Magnetoresistance Elements by M. Isai, T. Fukunaka and M. Ohshita.

Radiation-Induced Implantation of Polymeric Films in Metallic Substrates by M.W Ferralli and $M$. Luntz.

The Effect of Lateral Crack Growth on the Strength of Contact Flaws in Brittle Materials by R.F. Cook and D.H. Roach.

The Growth of AuGa2 Thin Films on GaAs (001) to Form Chemically Unreactive

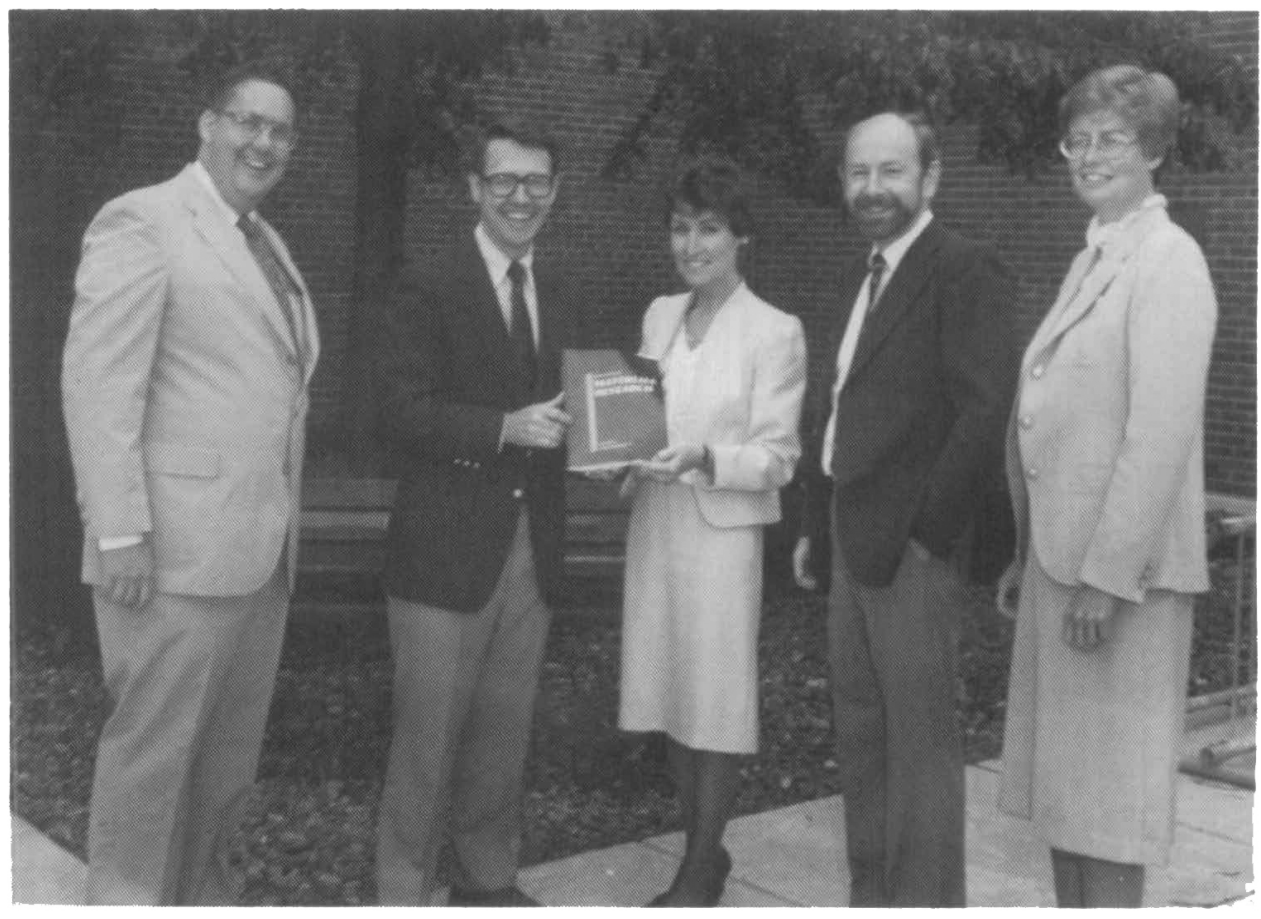

Linda J. Kennedy, supervisor of the editorial office of Journal of Materials Research, presents an autographed copy of the inaugural issue of JMR to Dr. Mark B. Myers, director of the Xerox Webster Research Center, where the editorial office is located. From left to right, are JMR Editor-in-Chief Charles B. Duke, Mark Myers, Linda Kennedy, Cliff Griffiths who indexes articles submitted to Journal of Materials Research, and Judith Stonehill, who is the author of the custom sof tware package used to process and track manuscripts in the editorial office. Dr. Myers, one of the founding members of the Materials Research Society, arranged for Xerox Corporation to provide financial support of the editorial office operation during the journal's initial year of operation. The editorial office is housed in Xerox facilities at the Webster Research Center and utilizes Xerox information systems products and customized software donated to the Materials Research Society by the Xerox Corporation.

(Photo by Floyd Johnson)

Interfaces by J.R. Lince, C. Thomas Tsai and R. Stanley Williams.

\section{Rapid Communication}

Ordering and Decomposition in Semiconductor Alloys by J.L. Martins and Alex Zunger.
Articles for consideration for future issues of Journal of Materials Research should be sent to Charles B. Duke, Editor-inChief, Journal of Materials Research, Xerox Webster Research Center, 800 Phillips Road, 0114/38D, Webster, NY 14580.

\section{Subscription Order Form for Journal of Materials Research}

1986 Subscription Rates:

$\square \$ 250$ - U.S. Surface
(Frequency: 6 times annually)

$\$ 257$ - Foreign Surface $\square \$ 265$ - Europe Optional Air Freight $\square \$ 273$ - Asia Optional Air Freight

Name

Institution

Last

First/Middle Initial

Address

Street and/or P.O. box 